\title{
Fleshing out the Ediacaran Period
}

\author{
J.G. Gehling \\ South Australian Museum, North Terrace, Adelaide, South Australia 5000, AUSTRALIA. \\ Email: gehling.jim@saugov.sa.gov.au
}

The Ediacaran Global Stratotype Section and Point has now been defined at the base of the Nuccaleena Formation in the Flinders Ranges National Park, South Australia. This GSSP marks the end of a major glacial epoch. In the absence of definitive biozones marking the base of the Ediacaran, the utility of this "cap carbonate' for correlation will depend on the verification of a global fingerprint based on the stratigraphic pattern, stable isotope trends and magnetostratigraphy. Even though the fossil record for the Ediacaran System is relatively sparse, it clearly characterizes this period on all continents except Antarctica. The task facing the Ediacaran Subcommission of the ICS is the correlation of the GSSP horizon around the globe and to foster biostratigraphic subdivision of the Ediacaran System.

In the Flinders Ranges National Park, the well exposed, structurally uncomplicated, 3.5-kmthick Ediacaran succession is capped with a 2-km-thick, fossiliferous Early Cambrian succession (Fig. 1). The Flinders Ranges Ediacaran succession preserves an apparently primary palaeomagnetic record, distinctive stratigraphic events, and fossils of the Ediacara biota at three well-separated levels.

- The palaeomagnetic record of the Elatina Formation, immediately below the Ediacaran GSSP, indicates that the Adelaide geosyncline experienced a protracted interval of glaciogenic sedimentation when the region was straddling the palaeomagnetic equator (Schmidt and Williams, 1995; Sohl, et al., 1999). New approaches to palaeomagnetic analysis promise a magnetostratigraphy for the Ediacaran succession in the Flinders Ranges.

- Within the lower Ediacaran Bunyeroo Formation, the distinctive Acraman ejecta layer can be traced throughout the Flinders Ranges and in deep bore holes from the coeval Officer Basin 400-600 km NW of the Flinders Ranges. Petrological and geochemical evidence 
sources the ejecta clasts from Lake Acraman, an eroded impact crater within the 1495 Ma porphyritic rhyolites of the Gawler Craton $300 \mathrm{~km}$ west of the Flinders Ranges (Gostin et al., 1986). The appearance of large, acanthomorphic acritarchs just above the Acraman ejecta layer, in bore holes from the Officer Basin, suggests a local perturbation on the communities of algal microfossils (Grey, et al., 2003).

- The Ediacaran succession of the Adelaide Geosyncline consists of at least 6 high order depositional sequences. At least three of the sequence boundaries involve $200-1200 \mathrm{~m}$ deep submarine valley and canyon incisions that record significant eustatic events (Christie-Blick, et al., 1990). These may correlate with excursions in the stable isotope and the palaeomagnetic record.

- Although certain claims of very early Ediacara fossils (Glaessner, 1968; Dyson, 1985) are now discounted, Palaeopascichnus, a serial branching body fossil (see Seilacher, et al., 2003), occurs in dense populations at the top of the Wonoka Formation, and again, $500 \mathrm{~m}$ above, within the more diverse Ediacara fossil assemblages of the Rawnsley Quartzite. As yet no radiometric dating is available to constrain the age of the fossiliferous Ediacara Member in the Rawnsley Quartzite. The Ediacara Member, spanning up to $300 \mathrm{~m}$ of section, consists of 2-5 parasequences, each with fossiliferous facies of slightly differing character (Gehling, 2000). The diverse and rich fossil assemblage of the Ediacara Member is notable for the co-occurrence of both trace fossils and body fossils. Since the Ediacara Member shares at least $65 \%$ of its described taxa with the White Sea fossil assemblages of northern Russia, it is arguable that they were coeval assemblages. The youngest Ediacara fossil horizon in the Flinders Ranges occurs $300-400 \mathrm{~m}$ above the Ediacara Member, just below the regional Ediacaran-Cambrian boundary (Fig. 1). Rippled surfaces bear large rimmed discs preserved much like the Cambrian medusoid fossils described by Hagadorn, et al. (2002) from the Late Cambrian of Wisconsin.

Globally, Ediacaran successions are diverse in their stratigraphy but share many characteristics of biostratigraphy, chemostratigraphy and event stratigraphy that can be calibrated with radiometric dating. 
- Megafossils are unknown from the earliest part of the Ediacaran. In Russia, the Ukraine, China, and in a number of other regions, organic walled microfossils (acritarchs) and algal fossils are important components of Ediacaran successions. A low diversity acritarch assemblage gives way to a more diverse assemblage of large spinous forms, here named the Sinian association for the stratigraphic interval preceding the Ediacara biota. The disappearance of the Sinian association in Central and South Australia (Grey, et al., 2003), just before the appearance of megafossils of the Ediacara biota has its parallel in southern China where it coincides with a post-Marinoan refrigeration event (Gaskiers?) and the advent of large algal fossils. Close packed compressions of the spherical alga, Beltanelliformis, occur in the Sinian association (Xiao, et al., 2002) and range up into the late Ediacaran. This makes Beltanelliformis one of the longest-lived and most widespread megafossils of the Ediacaran. While the stratigraphic relationships between Ediacara megafossils and organic walled microfossils and algae (e.g. vendotaenids) are still uncertain, it is clear that biostratigraphy of the Ediacaran will utilize fossils from the Ediacara biota, microfossil and algal associations.

- A parsimony analysis of endemism of 15 megafossil assemblages of the Ediacara biota, produced three clusters (Waggoner, 2003), here re-named for the most significant regions. Available radiometric calibration of Ediacaran successions supports the concept of distinct Avalon, Vendian and Namibian associations as a temporal succession (Waggoner, 2003), rather than simply environmental (Grazhdankin, 2004) or palaeobiogeographic assemblages. The fact that the Avalonian association is found in deep-water facies in Newfoundland, England and Wales, whereas the more diverse Vendian association is preserved in relatively shallow marine environments, does not exclude a temporal separation. The successions of northwestern Canada, although relatively sparse, show a stratigraphic shift from an Avalonian association to a Vendian association, even though the environments represented are outer shelf and slope (Narbonne and Aitken, 1995). The Namibian association spans diverse environments. The utility of proposed assemblage zones will require a review of taxonomy and assessment of ranges of cosmopolitan Ediacara genera. 
- Within the 575 - 565 Ma time span of the Avalon association in SE Newfoundland, there is a significant stratigraphic increase in taxonomic diversity. It is now clear that no trace fossils or fossils with bilaterian body plans are known from this earliest association. At around $560 \mathrm{Ma}$, there was a simultaneous appearance of bilaterian body fossils and trace fossils coinciding with a decrease in dominance of fractal-growth or frondose taxa in the Vendian association. The first calcified skeletons appear in the Namibian association. These biological events are interpreted as evolutionary stages in the Ediacara biota, rather than simply environmental differences.

- Two of the most significant negative excursions of $\partial^{13} \mathrm{C}_{\text {carb }}$ values, that have ever been recorded, mark the beginning and end of the Ediacaran period (Shields, 1999; Walter et al., 2000). A less prominent mid-Ediacaran excursion also seems to have coincided with a eustatic fall in sea level (Shields, 1999). Considered along with trends in ${ }^{87} \mathrm{Sr} /{ }^{86} \mathrm{Sr}$ ratios and $\partial^{34} S_{\text {sulfate }}$ values, a first order partitioning of Ediacaran time is possible (Walter et al. 2000). The weakening oscillation of $\partial^{13} \mathrm{C}_{\text {carb }}$ values, from the early Cambrian onward, may reflect the geochemical feedback due to biological activities. The first carbonate secreting organisms, and reworking of organic matter at the sediment interface by infaunal burrowers, were key innovations in the ecological revolution that accompanied the rapid Cambrian expansion in number and diversity of metazoans.

- On the Avalon Peninsula of SE Newfoundland, fossils of the Avalon association are bracketed by volcanic ash beds with U-Pb zircons ages of 575.4 $\pm 0.4 \mathrm{Ma}$ (Bowring, et al. 2003) and 565 $\pm 3 \mathrm{Ma}$ (Benus, et al., 1988) respectively. The Vendian association of the Ust Peniga Group, White Sea region, Russia, spans volcanic units with U-Pb zircon ages of $558 \pm 1$ Ma (Grazhdankin, 2004) and 555.3 \pm 0.3 Ma (Martin et al., 2000). In Namibia, the Namibian association ranges from somewhat older than $548.9 \pm 1$ Ma to a little younger than $543.3 \pm 1 \mathrm{Ma}$.

The challenge to document the tempo and pattern of evolution of early animals and the associated changes in global climate make the subdivision and calibration of the Ediacaran a vital task for the next decade. 


\section{References}

Benus, A.P. 1988. Sedimentological context of a deep-water Ediacaran fauna (Mistaken Point Formation, Avalon Zone, Eastern Newfoundland): 8-9. In Landing, E. Narbonne, G.M. and Myrow, P. (eds). Trace fossils, small shelly fossils and the Precambrian-Cambrian Boundary. Bulletin of the New York State Museum 463: 1-81.

Bowring, S.A., Myrow, P., Landing, E. and Ramenzani, J. 2003. Geochronological constraints on terminal Neoproterozoic events and the rise of metazoans. NASA Astrobiology Institute General Meeting, Abstract \#13045, 113-114.

Christie-Blick, N., von der Borsch, C.C., and DiBona, P.A., 1990. Working hypotheses for the origin of the Wonoka Canyons (Neoproterozoic), South Australia. American Journal of Science 290, 295-332.

Dyson, I. A. 1985. Frond-like fossils from the base of the late Precambrian Wilpena Group, South Australia. Nature 318, 283-285.

Gehling, J.G., 2000. Sequence stratigraphic context of the Ediacara Member, Rawnsley Quartzite, South Australia: a taphonomic window into the Neoproterozoic biosphere. Precambrian Research 100, 65-95.

Glaessner, M.F. 1968. Trace fossils from the Precambrian and basal Cambrian. Lethaia 2, 369-393.

Gostin, V.A., Haines, P.W., Jenkins, R.J.F., Compston, W. and Williams, I.S. 1986. Impact ejecta horizon within late Precambrian shales, Adelaide Geosyncline, South Australia. Science $233,198-200$.

Grazhdankin, D. 2004. Structure and depositional environment of the Vendian complex in the Southeastern White Sea area. Stratigraphy and Geological Correlation 11, 313-331.

Grey, K., Walter, M.R., and Calver, C.R., 2003, Plankton and isotope changes at the late Neoproterozoic Acraman impact ejecta layer: Geology, 31: 459-462.

Hagadorn, J.W., Dott Jr., R.H. and Damrow, D. 2002. Stranded on a Late Cambrian shoreline: medusae from central Wisconsin. Geology, 30, 147-150.

Grotzinger, J.P., Bowring, S.A., Saylor, B.Z. and Kaufman, A.J. 1995. Biostratigraphic and geochronologic constraints on early animal evolution. Science 270 : 598-604. 
Martin, M.W., Grazhdankin, D.V., Bowring, S.A., Evans, D.A.D., Fedonkin, M.A., and Kirschvink, J.L., 2000. Age of Neoproterozoic bilaterian body and trace fossils, White Sea, Russia: Implications for metazoan evolution: Science 288, 841-845.

Narbonne, G.M., and Aitken, J.D. 1995. Neoproterozoic of the Mackenzie Mountains, northwestern Canada. Precambrian Research 73, 101-121.

Schmidt, P.W., and Williams, G.E., 1995, The Neoproterozoic climate paradox: Equatorial palaeolatitude for Marinoan glaciation near sea level in South Australia. Earth and Planetary Science Letters 134, 107-124.

Sohl, L.E., Christie-Blick, N., and Kent, D.V., 1999, Paleomagnetic polarity reversals in Marinoan (ca. $600 \mathrm{Ma}$ ) glacial deposits of Australia: Implications for the duration of lowlatitude glaciation in Neoproterozoic time. Geological Society of America Bulletin, 111, 1120-1139.

Seilacher, A., Grazhdankin, D., and Legouta, A. 2003. Ediacaran biota: the dawn of animal life in the shadow of giant protists. Paleontological Research 7, 43-54.

Shields, G. 1999. Working towards a new stratigraphic calibration scheme for the Neoproterozoic-Cambrian. Eoclogae Geologicae Helvetiae 92, 221-233.

Waggoner, B. 2003. The Ediacaran biotas in time and space. Integrative and Comparative Biology 43, 104-113.

Walter, M.R., Veevers, J.J., Calver, C.R., Gorjan, P. and Hill, A.C. 2000. Dating the 840-544 Ma Neoproterozoic interval by isotopes of strontium, carbon, and sulfur in seawater and some interpretive models. Precambrian Research 100: 371-433.

Xiao, S, Xunlai, Y., Steiner, M., and Knoll, A.H. 2002. Macroscopic carbonaceous compressions in a terminal Proterozoic shale: a systematic reassessment of the Miaohe biota, South China. Journal of Paleontology 76, 347-376. 


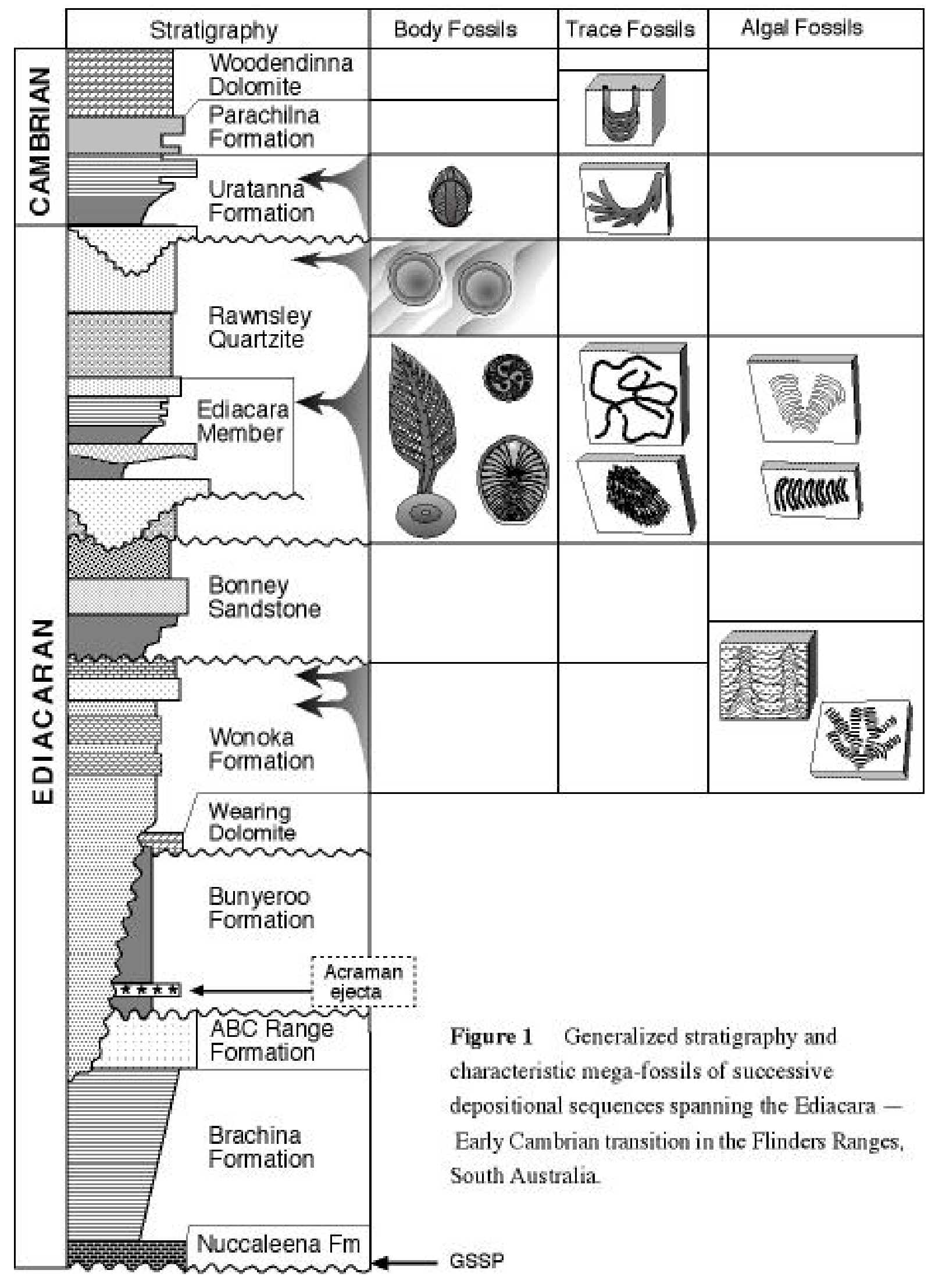

